\title{
Perlindungan Hukum Terhadap Hak Cipta Atas Batik di Kota Serang Provinsi Banten
}

\author{
1Sulasno, ${ }^{2}$ Mia Mukaromah \\ Fakultas Ilmu Sosial, Ilmu Politik dan Ilmu Hukum, Universitas Serang Raya, Serang. \\ Email: sulasno1971@gmail.com
}

\section{Info Artikel:}

\begin{abstract}
This writing aims to find out how the legal protection of the copyright of batik in the city of Serang with the provisions contained in Law No. 28 of 2014 concerning Copyright and regional regulations governing the protection of copyright in the city of Serang.But now researchers have not found any specific regional regulations governing Copyright (Batik Art) in Serang City. Batik is one of the works of art that requires high intellectuals in its creation. Legal protection of batik copyrights is needed to avoid things that will harm the creator and the copyright holder. The method used is the empirical normative legal research method, namely the incorporation of normative legal provisions (laws) with empirical elements (legal events in society / social elements).
\end{abstract}

Keywords: Legal Protection; Copyright; Batik Art;

\begin{abstract}
Abstrak
Penulisan ini bertujuan untuk mengetahui bagaimana perlindungan hukum terhadap hak cipta batik di Kota Serang dengan ketentuan yang ada dalam Undang-Undang Nomor 28 Tahun 2014 tentang Hak Cipta dan peraturan daerah yang mengatur tentang perlindungan terhadap hak cipta di Kota Serang. Namun saat ini peneliti belum menemukan adanya peraturan daerah secara khusus yang mengatur tentang Hak Cipta (Seni Batik) di Kota Serang. Batik merupakan salah satu karya seni yang memerlukan intelektual yang tinggi dalam penciptaannya. Perlindungan hukum terhadap hak cipta batik sangat diperlukan untuk menghindari hal yang akan merugikan bagi pencipta dan pemegang hak cipta. Metode yang digunakan adalah metode penelitian hukum normatif empiris yaitu penggabungan dari ketentuan hukum normatif (undang-undang) dengan unsur-unsur empiris (peristiwa hukum di masyarakat/unsur sosial).
\end{abstract}

Kata Kunci: Perlindungan Hukum; Hak Cipta;Seni Batik; 


\section{A. PENDAHULUAN}

Indonesia dikenal sebagai bangsa yang memiliki kekayaan budaya yang sangat beragam. Keberagaman tersebut menjadikan Indonesia sebagai bangsa yang memiliki ciri khas dan kaya dalam kebudayaan. Warisan tersebut sepatutnya dijaga sebagai jati diri bangsa, salah satunya adalah dengan mengeluarkan produk hukum berupa peraturan perundang-undangan yang mengatur tentang perlindungan warisan kebudayaan agar terjamin oleh hukum keberadaannya. Hak Kekayaan Intelektual (HKI) adalah hak kebendaan, hak atas suatu benda yang bersumber dari hasil kerja otak, hasil kerja ratio. ${ }^{1}$ Hasil kerja otak tersebut kemudian dirumuskan sebagai intelektualitas yang memiliki suatu keistimewaan dan patut untuk diapresiasi. Tidak semua orang dapat dan mampu memperkerjakan intelektualnya secara maksimal.Tidak semua orang pula dapat menghasilkan suatu intelektualitas. Hanya orang yang mampu memaksimalkan otak (nalar, ratio, intelektualitas) sajalah yang dapat menghasilkan hak kebendaan yang disebut intellectual property rights. Sebab itulah hak atas kekayaan intelektual itu bersifat ekslusif yang berlaku hanya untuk orang tertentu saja.Di dalam bidang Hak Cipta (copyright), yang merupakan bagian HKI terkandung hak-hak eksploitas atau hak-hak ekonomi (economic rights) dan hak-hak moral (moral rights). Oleh karena itu suatu ciptaan jika tidak dikelola secara tertib dengan aturan-aturan hukum dapat memberikan sengketa kepada pemilik hak

1 Saidin, aspek hukum hak kekayaan intelektual, Jakarta: Raja Grafindo Persada,2003, hlm.9 cipta dengan pengelola hak cipta atau pihak lain yang melanggarnya.

Indonesia memiliki hukum positif terbaru tentang hak cipta yaitu UndangUndang Nomor 28 Tahun 2014 tentang Hak Cipta.Dalam Pasal 1 Ayat (1) Undang-Undang Nomor 28 Tahun 2014 menyebutkan "Hak Cipta adalah hak ekslusif pencipta yang timbul secara otomatis berdasarkan prinsip deklaratif setelah suatu ciptaan diwujudkan dalam bentuk nyata tanpa mengurangi pembatasan sesuai dengan ketentuan peraturan perundang-undangan." Perlindungan terhadap hak cipta dalam Undang-Undang tersebut meliputi bidang ilmu pengetahuan, seni, dan sastra, mencakup: Buku, program komputer, pamflet, perwajahan (lay out), karya tulis yang diterbitkan, dan semua hasil karya tulis lain. Ceramah, kuliah, pidato, dan Ciptaan lain yang sejenis dengan itu. Alat peraga yang dibuat untuk kepentingan pendidikan dan ilmu pengetahuan. Lagu atau musik dengan atau tanpa teks Drama atau drama musikal, tari, koreografi, pewayangan, dan pantomim. Seni rupa dalam segala bentuk seperti seni lukis, gambar, seni ukir, seni kaligrafi, seni pahat, seni patung, kolase, dan seni terapan, arsitekstur, peta, seni batik, fotografi, sinematografi, terjemahan, tafsir, saduran, bunga rampai, database dan karya lain dari hasil pengalihwujudan.

Seni batik merupakan warisan budaya bangsa Indonesia yang memiliki potensi penggerak ekonomi dan juga sebagai identitas bangsa. Karya seni batik merupakan perwujudan intelektual yang kreatif dan biasanya memiliki ciri khas tertentu pada daerahnya masing-masing. Sebenarnya tidak hanya di Indonesia 
terdapat juga seni batik di beberapa negara lain namun motif seni batik Indonesia dinilai lebih kreatif, unik dan memiliki makna tersendiri atau berkarakter. Eskistensi batik saat ini semakin kuat. Dunia pun mengakui batik merupakan salah satu warisan umat manusia yang dihasilkan oleh bangsa Indonesia. Hal tersebut secara resmi diakui oleh UNSESCO (United Nations Educational, Scientific, and Culture Organization) dengan dimasukkan ke dalam daftar representatif sebagai budaya tak-benda warisan manusia (Representative List of The Intangible Cultural Heritage of Humanity). ${ }^{2}$

Dengan adanya pengakuan UNESCO citra batik menjadi sangat diakui baik tingkat nasional maupun internasional. Batik dianggap sebagai hasil karya seni turun-temurun yang harus dijaga kelestariannya. Setiap motif batik yang diciptakan disuatu daerah akan berbeda dengan daerah lainnya. Hal tersebut berkaitan erat dengan keadaan pada wilayah penciptaan batik. Motif pada seni batik seringkali dihubungkan dengan kehidupan yang terjadi pada suatu daerah tertentu yang bermakna khusus dalam budaya mereka. Begitupula pada Batik Banten yang memiliki unsur-unsur nilai historis, estetika dan etika Banten. Keberadaan Batik Banten tidak sesederhana yang kita pikirkan, ada proses panjang hingga munculnya Batik Banten. Sebenarnya sumber estetika pada Batik Banten telah ditemukan pertama kali pada tahun 1976 pada masa eskavasi di situs

${ }^{2}$ Ibid, hlm. 117
Banten Lama. $^{3}$ Pada masa tersebut masyarakat lebih banyak menciptakan karya seni pada ragam hias gerabah, ragam hias pada nisan-nisan kuna, ragam hias pada naskah-naskah kuna dan ragam hias pada nisan-nisan kuna. Sementara apresiasi pada ragam hias sebuah kain (batik) masih belum ada.

Tahun 1992 upaya-upaya membatik di Banten sudah mulai muncul. Motif yang dimunculkan berupa gambargambar binatang seperti, harimau, kerbau, gajah dan badak bercula satu namun batik tersebut tidak berumur lama. Pada tahun 2005 terdapat upaya pembangkitan kembali Batik Banten dengan lahirnya Industri Batik Banten Mukarnas yang telah menjadi pelopor teknik cetak dan printing yang kemudian berkembang lagi terdapat teknik cetak dan tulis. Motifnya pun menjadi sangat beragam dan lebih modern. Data sementara yang peneliti dapatkan saat ini dari Kanwil Kementrian Hukum dan HAM Provinsi Banten di Kota Serang terdapat beberapa daerah yang telah mendaftarkan hak cipta pada motif Batik Banten kecuali Kota Serang yang sampai saat ini belum mendaftarkan hak cipta karya seni batik ke Kanwil Kementrian Hukum dan HAM Provinsi Banten. Hal ini mungkin terjadi karena dalam pendaftaran Hak Cipta bisa melalui berbagai jalur salah satunya pada Kanwil Kementrian Hukum dan HAM di daerahnya masing-masing. Oleh karena itu diperlukan banyak data tambahan dengan cara penelitian yang lebih mendalam terkait Perlindungan Hukum Terhadap Hak Cipta Batik di Kota Serang.

\footnotetext{
${ }^{3}$ Tubagus Najib, Batik Banten Mukarnas Tranformasi Motif Terwengkal ke Motif Lain, Sengpho Utama, 2012, hlm.2
} 


\begin{abstract}
Dari uraian diatas menjadi landasan dasar bagi peneliti dalam melaksanakan penelitian tentang Perlindungan Hukum Terhadap Hak Cipta Batik di Kota Serang terhadap bentuk perlindungan hukum Batik di kota Serang serta penerapan kebijakan pemerintah Kota Serang dalam perlindungan Hak Cipta atas Batik.
\end{abstract}

\section{B. METODE PENELITIAN}

Metode penelitian yang digunakan dalam penelitian ini adalah dengan metode penelitian hukum normatif empiris. Metode penelitian normatif empiris merupakan penelitian melihat dari hukum yang bekerja pada segi kaidah/norma berupa peraturan perundang-undangan yang berkaitan dengan hak cipta dengan tidak terlepas dari unsur sosial/empiris yakni kenyataan yang ada dimasyarakat adanya pemahaman juga perlindungan yang kurang maksimal terkait hak cipta seni batik. Teknik dalam pengumpulan data dengan cara studi pustaka yaitu teknik pengumpulan dan informasi dengan menelaah sumber-sumber tertulis yang relevan dan berhubungan dengan objek yang sedang diteliti sehingga mampu menjawab permasalahan yang dihadapi. Analisis data dilakukan secara kualitatif yaitu dengan menelaah seluruh data yang tersedia kemudian dilakukan reduksi data sehingga menghasilkan penafsiran data yang sesuai dengan tujuan penelitian.

\section{HASIL DAN PEMBAHASAN}

\section{Perkembangan Perlindungan Hak} atas Kekayaan Intelektual

HKI (Hak Kekayaan Intelektual) disebut sebagai "creation of mind" yang berarti suatu karya manusia yang lahir dengan curahan tenaga, karsa, cipta, waktu dan biaya. ${ }^{4}$ HKI kini sudah banyak macamnya. Dalam persetujuan umum tentang Tarif dan Perdagangan (General Agreement of Tariff and TradeGATT) sebagai bagian dari pembentukan organiasai perdagangan dunia (WTO) telah disepakati pula norma-norma dan standar perlindungan HAKI, antaranya: 1) Hak Cipta dan Hak lain terkait (copyright and relatedrights); 2) merek (trademarks, servicemarks, and trade name); 3) indikasi geografis (gheographical indications); 4) desain produk industri (industrial desain); 5) paten (patens) termasuk perlimdungan varietas tanaman; 6) desain tata letak sirkuit terpadu (layout-de-signs (topoghraphy of integrated circuits); 7) perlindungan terhadap informasi yang dirahasiakan (protection of undisclosed information); dan 8) pegendalian praktikpraktik persaingan curang dalam perjanjian lisensi (control of anticompetitive practies in contractural licences). ${ }^{5}$

Secara khusus Hak Cipta yang merupakan bagian dari kekayaan intelektual diatur pada Undang-Undang

\footnotetext{
${ }^{4}$ Sulasno, Ajudikasi : Jurnal Ilmu Hukum: Penerapan Kekayaan Intelektual (KI) Terhadap Umkm Sebagai Upaya Mewujudkan Persaingan Bisnis Berkeadilan, Vol.2, No.2, Desember 2018, hlm.179

5 Devi Rahayu, jurnal Mimbar Hukum :Perlindungan Hukum Terhadap Hak Cipta Motif Batik Tanjungbumi Madura, Vol 23, Nomor.1, , 01 Februari 2011, hlm 116
} 
Nomor 28 Tahun 2014 Tentang Hak

Cipta perubahan atas Undang-Undang Nomor 19 Tahun 2002 Tentang Hak Cipta yang dianggap sudah tidak sesuai dengan perkembangan hukum dan kebutuhan masyarakat. Dalam UndangUndang Hak Cipta terdapat ciptaan yang dilindungi dan ciptaan yang tidak dilindungi. Ciptaan yang dilindungi meliputi ciptaan dalam bidang ilmu pengetahuan, seni dan sastra terdiri dari:

a. Buku, pamphlet, perwajahan karya tulis yang diterbitkan, dan semua hasil karya tulis lainnya

b. Ceramah, kuliah, pidato, dan ciptaan sejenis lainnya

c. Alat peraga yang dibuat untuk kepentingan pendidikan dan ilmu pengetahuan

d. Lagu dan/atau musik dengan atau tanpa teks

e. Drama, drama musikal, tari, koreografi, pewayangan dan pantomime

f. Karya seni rupa dalam segala bentuk seperti lukisan, gambar, ukiran, kaligrafi, seni pahat, patung atau kolase

g. Karya seni terapan

h. Karya arsitektur

i. Peta

j. Karya seni batik atau seni motif lain

k. Karya fotografi

1. Potret

m. Karya sinematografi

n. Terjemahan, tafsir saduran, bunga rampai, basis data, adaptasi, aransemen, modifikasidan karya lain dari hasil transformasi o. Terjemahan, adaptasi, aransemen, transformasi atau modifikasi ekspresi budaya tradisional

p. Kompilasi ciptaan atau data, baik dalam format yang bisa dibaca dengan program computer maupun media lainnya

q. Kompilasi ekspresi budaya tradisional selama kompilasi tersebut merupakan karya yang asli

r. Permainan video

s. Program komputer Sedangkan hasil karya yang tidak dilindungi Hak Cipta, antaranya:

a. Hasil karya yang belum diwujudkan dalam bentuk nyata

b. Setiap ide, prosedur, sistem metode, konsep, prinsip, temuan atau data walaupun telah diungkapkan, dinyatakan, digambarkan, dijelaskan atau digabungkan dalam sebuah ciptaan dan

c. Alat benda, atau produk yang diciptakan hanya untuk menyelesaikan masalah teknis atau yang bentuknya hanya ditunjukan untuk kebutuhan fungsional.

Dalam perlindungan Hak Kekayaan Intelektual terhadap hak cipta atas batik terdapat prinsip-prinsip hukum kekayaan intelektual.Prinsip-prinsip tersebut antara lain prinsip keadilan, prinsip ekonomi, dan prinsip sosial dan budaya. Prinsip-prinsip tersebut bila dijabarkan sebagai berikut: ${ }^{6}$

a) Prinsip Ekonomi, yakni hak intelektual dari kegiatan kreatif

${ }^{6}$ Sulasno, Op.Cit, hlm. 180 
suatu kemauan daya pikir manusia yang diekspresikan dalam berbagai bentuk yang akan memberikan keuntungan kepada pemilik yang bersangkutan. Begitu pula pada hasil karya seni batik di Kota Serang yang dapat dimaksimalkan sehingga memberikan keuntngan secara ekonomi bagi pencipta maupun pemegang hak cipta juga masyarakat sekitar.

b) Prinsip Keadilan, yakni di dalam menciptakan sebuah karya atau orang yang bekerja membuahkan suatu hasil dari kemampuan intelektual dalam ilmu pengetahuan, seni, dan sastra yang akan mendapat perlindungan dalam pemiliknya. Demikian juga dalam kepemilikan hak cipta atas seni batik maka secara wajar dan addil dapat dinikmati olehnya. Bila dilihat dari teori keadilan maka dianggap adil dan wajar apabila pemilik atau pemegang hak cipta menggunakan dan menjual produk atas karya cipta seni batiknya yang dihasilkan dari olah pikirnya.

c) Prinsip Kebudayaan, yakni perkembangan ilmu pengetahuan, sastra, dan seni adalah untuk meningkatkan kehidupan manusia. Seni batik merupakan salah satu budaya di Kota Serang yang belum dikembangkan secara maksimal. Oleh karena itu dengan penelitian ini diharapkan dapat membantu dalam peningkatan perkembangan seni batik di Kota Serang untuk meningkatkan kesejahteraan daerahnya dan menjaga kebudayaan agar tetap terjaga dengan baik.

d) Prinsip Sosial yaitu mengatur kepentingan manusia sebagai warga negara, artinya hak yang diakui oleh hukum dan telah diberikan kepada individu merupakan satu kesatuan sehingga perlindungan diberikan berdasarkan keseimbangan kepentingan individu dan masyarakat.

\section{Perlindungan Hak Cipta Atas Batik di Kota Serang Provinsi Banten}

Istilah hak cipta diusulkan pertama kalinya oleh Prof. St. Moh. Syah, S.H, pada kongres kebudayaan di Bandung tahun 1951 sebagai pengganti istilah hak penggarang yang dianggap masih terlalu luas cakupannya dalam pengertiannya. Hak pengarang itu sendiri merupakan terjemahan dari bahasa Belanda Auteurs Recht. Hak Cipta adalah hak ekslusif pencipta yang timbul secara otomatis berdasarkan prinsip deklaratif setelah suatu ciptaan diwujudkan dalam bentuk nyata tanpa mengurangi pembatasan sesuai dengan ketentuan peraturan perundang-undangan. ${ }^{7} \quad$ Sedangkan pengertian hak cipta menurut Auteuswet 1912 dan Universal Copyright Convention. ${ }^{8}$ Auteuswet menyebutkan "Hak Cipta adalah hak tunggal dari pencipta atau hak yang mendapat hak tersebut, atas hasil

\footnotetext{
${ }^{7}$ Undang-Undang Nomor 28 Tahun 2014 Tentang Hak Cipta (TLNRI) Nomor 5599

${ }^{8}$ Saidin, Op.Cit hlm 58
} 
ciptaannya dalam lapangan

kesusteraan, pengetahuan dan kesenian, untuk mengumumkan dan memperbanyak dengan mengingat pembatasan-pembatasan yang ditentukan oleh undang-undang."

$$
\text { Universal Copyright }
$$

Convention Dalam pasal V menyatakan "Hak Cipta meliputi hak tunggal si pencipta untuk membuat menerbitkan dan memberi kuasa untuk membuat terjemah dari karya yang dilindungi perjanjian ini." Hak cipta sebagai hak ekslusif berarti hak khusus, spesifik dan unik. Karena tidak semua orang dapat menciptakan suatu karya yang memiliki hak cipta. Hanya orang yang memiliki kecerdasan intelektual yang tinggi yang dapat berkreasi untuk menghasilkan karya cipta. Hak Cipta memberikan hak-hak tertentu kepada para pencipta dan pemegang hak cipta untuk memberikan wewenang atau melarang untuk menggunakan suatu ciptaan (karya) tersebut selama waktu tertentu. ${ }^{9}$

Hak cipta merupakan salah satu jenis hak kekayaan intelektual namun hak cipta sangat berbeda dari hak kekayaan intelektual lainnya. Seperti hak paten yang memberikan monopoli pada penggunaan penemuannya. Sedangkan hak cipta bukan hak monopoli untuk melakukan sesuatu pada hasil karya ciptanya, melainkan hak untuk mencegah orang lain melakukan

9 Margono Suyud, Hukum Hak Cipta Indonesia (Teori Analisis Harmonisasi Ketentuan World Trade Organization (WTO)-TRIPs Agreement), Bogor: Ghalia Indonesia, hlm. 25 pelanggaran-pelanggaran terhadap hak cipta tersebut. Dalam hak cipta antara pencipta dan pemegang hak cipta boleh orang yang berbeda dengan beberapa ketentuan yang telah diatur pada undang-undang misalnya dengan royalti.

Seni batik adalah sebuah teknik menggambar di atas kain dan memanfaatkan lilin dan canting sebagai bahan dan alat untuk membuatnya. Menurut Nusjirwan Tirtaamidjaja seni batik adalah teknik menghias kain atau tekstil dengan menggunakan lilin dalam proses pencelupan warna, yang semua proses tersebut menggunakan tangan. Afifa Syakur menyatakan batik adalah serentang warna meliputi proses pemalaman (lilin), pencelupan (pewarnaan) dan pelorotan (pemanasan), hingga menghasilkan motif yang halus yang semuanya ini memerlukan ketelitian yang tinggi. Batik merupakan salah satu karya seni rupa terapan yang dapat digunakan untuk berbagai kebutuhan seperti pakaian. Batik di Indonesia memiliki banyak ragam dan sudah mendapat tempat di hati masyarakatnya. Semua orang pasti sudah kenal batik, mulai dari anak kecil sampai orang dewasa.Batikpun saat ini sudah memiliki motif yang sangat beragam dan modern sehingga penggunaannya tidak terkesan ketinggalan jaman. Batik termasuk dalam karya cipta yang memiliki perlindungan dalam Undang-Undang Nomor 28 Tahun 2014 Tentang Hak Cipta. 
Perlindungan hukum terhadap

Hak Cipta di Indonesia telah mengalami proses yang panjang. Beberapa kali perubahan pada peraturan perundang-undangan tentang hak cipta menandakan ada upaya yang serius dari pemerintah untuk melindungi hak cipta bagi masyarakatnya. Undang-Undang Nomor 28 Tahun 2014 Tentang Hak Cipta adalah hasil perubahan dari Undang-Undang Nomor 19 Tahun 2002 Tentang Hak Cipta yang dianggap sudah tidak sesuai dengan perkembangan hukum dan kebutuhan masyarakat saat ini sehingga perlu diganti dengan undang-undang yang baru.

Perlindungan terhadap suatu ciptaan timbul secara otomatis sejak ciptaan itu diwujudkan dalam bentuk nyata. ${ }^{10}$ Pendaftaran suatu ciptaan tidak merupakan hal yang wajib dilakukan, namun pencipta dan pemegang hak cipta yang mendaftarkan hak ciptanya akan diberikan surat pendaftaran. Surat tersebut bisa dijadikan sebagai alat bukti yang kuat jika suatu saat terjadi sengketa terhadap ciptaan tersebut. Jika dilihat dari Undang-Undang Nomor 28 Tahun 2014 Tentang Hak Cipta perlindungan hak ekonomi dan hak moral para pencipta dan pemilik hak cipta merupakan unsur penting dalam pembangunan kreativitas nasional. Sebelum mengetahui bentuk perlindungan terhadap Hak Cipta kita harus tahu terlebih dahulu yang

10 Palup Trias, Jurnal Negara Hukum:Materi Baru Dalam Undang-Undang Nomor 28 Tahun 2014 Tentang Hak Cipta, Vol.6, No.1, Juli 2015, hlm.97 disebut sebagai pencipta dan pemegang/pemilik hak cipta.

$$
\text { Menurut Undang-Undang }
$$

Nomor 28 Tahun 2014 Tentang Hak Cipta "pencipta adalah seorang atau beberapa orang yang secara sendirisendiri atau bersama-sama menghasilkan suatu ciptaan yang bersifat khas dan pribadi." Atau secara singkat pencipta dapat diartikan sebagai orang yang menghasilkan ciptaan. Sedangkan pemegang hak cipta adalah sebagai pemilik hak cipta, pihak yang menerima hak tersebut secara sah dari pencipta atau pihak lain yang sebelumnya telah menerima hak tersebut secara sah. Hal ini berarti antara pencipta dan pemegang hak cipta boleh orang yang berbeda dengan ketentuan yang ada dalam Undang-Undang Hak Cipta. Beberapa bentuk perlindungan Hak Cipta dalam Undang-Undang Nomor 28 Tahun 2014 Tentang Hak Cipta, antara lain:

a. Perlindungan berupa hak moral

Hak moral merupakan hak yang melekat secara abadi pada diri pencipta, tidak dapat dialihkan selama pencitpta masih hidup. Tetapi, pelaksanaan hak tersebut dapat dialihkan dengan wasiat atau sebab lain sesuai dengan ketentuan peraturan perundang-undangan setelah pencipta meninggal dunia. Hak moral berlaku bagi pencipta untuk:

a. tetap mencantumkan atau tidak mencantumkan namanya pada salinan sehubungan dengan 
pemakaian ciptaannya

untuk umum

b. menggunakan nama aliasnya atau samarannya

c. menggunakan ciptaannya sesuai dengan kepatutan dalam masyarakat

d. mengubah judul dan anak judul ciptaan

e. mempertahankan haknya dalam hal terjadi distorsi ciptaan, mutilasi ciptaan, modifikasi ciptaan atau hal yang bersifat merugikan kehormatan diri atau reputasinya.

Dalam perlindungan Hak Moral pencipta dapat memiliki:

a. Informasi manajemen Hak Cipta meliputi, metode atau sistem yang dapat mengidentifikasi

originalitas substansi Ciptaan dan Penciptanya, kode informasi dan kode akses.

b. Informasi elektronik Hak Cipta meliputi, suatu ciptaan yang muncul dan melekat secara elektronik dalam hubungan dengan kegiatan pengumuman ciptaan, nama pencipta boleh nama aliasnya atau nama samaran, pencipta sebagai pemegang hak cipta, masa dan kondisi penggunaan ciptaan, nomor dan kode informasi. Informasi manajemen Hak Cipta dan informasi elektronik Hak Cipta yang telah disebutkan di atas dimiliki pencipta dilarang dihilangkan, diubah atau dirusak. Perlindungan Hak Moral pada Hak Cipta seni batik berlaku selama hidup pencipta dan terus berlangsung selama 70 (tujuh puluh) tahun setelah pencipta meninggal dunia. Hal tersebut bertujuan untuk menghormati dan melindugi pencipta.

b. Perlindungan berupa hak ekonomi

Hak ekonomi adalah hak ekslusif Pencipta atau Pemegang Hak Cipta untuk mendapatkan manfaat ekonomi atas ciptaan.Hak ekonomi dapat dilaksanakan hanya bila mendapatkan izin Pencipta atau Pemegang Hak Cipta. Hak ekonomi atas suatu ciptaan dapat dialihkan dengan seizin pencipta dan pemegang hak cipta. Pemilik hak ekonomi memiliki hak untuk:

a. penerbitan ciptaan

b. penggandaan ciptaan dalam segala bentuknya

c. penerjemahan ciptaan

d. pengadaptasian, pengaransemenan, atau pentransformasian ciptaan

e. pendistribuan ciptaan atau salinannya

f. pertunjukan ciptaan

g. pengumuman ciptaan

h. komunikasi ciptaan

i. penyewaan ciptaan Dalam Undang-Undang Hak Cipta terbaru diatur materi baru mengenai perlindungan terhadap pengalihan hak ekonomi dalam bentuk jual putus (sold flat) namun hanya berlaku pada karya bentuk ciptaan buku dan/atau 
semua hasil karya tulis lainnya, lagu dan/atau musik dengan atau tanpa teks. Terkait dengan masalah penyelesaian sengketa pada Undang-Undang Hak Cipta pada dasarnya telah mengatur ketentuan pidana di dalamnya. Namun penggunaan hukum pidana teteaplah dijadikan sebagai upaya terakhir (ultimum remedium) setelah upaya lain misalnya mediasi, arbitrase dirasa kurang memuaskan.

\section{Penerapan Kebijakan Pemerintah Kota Serang dalam Perlindungan Hak Cipta atas Batik}

Batik banten adalah batik yang berasal dari provinsi Banten bersumber dari kearifan lokal yang tersisa dari pusat kerajaan pemerintah Islam Kesultanan Banten, telah mewarisi berbagai benda-benda kuno yang mempunyai ragam khas dan unik. Lewat warisan tersebut masyarakat dapat mengukir karyakarya seni batik yang menjadi unggulan di Banten.Saat ini kajian pemanfaatan benda-benda kuno khas Banten telah ditransformasikan dan didesain ke dalam media kain katun dan sutra yang disebut Batik Banten. Batik Banten tidak hanya dikenal secara lokal saja melainkan sudah masuk ke kancah internasional. Pada tahun 2003 Batik Banten mengajukan Hak Paten atas motifnya yang membuat Batik Banten menjadi satusatunya di Indonesia yang motifnya telah dipatenkan.

Hukum dalam kehidupan bermasyarakat bertujuan untuk menjaga dan melindungi kepentingan-kepentingan masyarakat dari hal-hal yang bertentangan sehingga menghindari segala bentuk sengketa di dalamnya.Seperti yang kita tahu bahwa Indonesia adalah negara hukum yang berarti segala bentuk aktivitas di negara Indonesia harus ada pengaturan hukumnya. Ketentuan hukum dan segala peraturan yang dibuat oleh masyarakat merupakan kesepakatan bersama untuk mengatur hubungan perilaku diantara anggota masyarakatmasyarakat dan antara perseorangan dengan pemerintah yang dianggap mewakili kepentingan masyarakat.

$$
\text { Dalam }
$$

UUD

1945

memberikan perlindungan hukum bagi setiap warga negara Indonesia tanpa terkecuali, untuk itu setiap produk atau kebijakan yang dikeluarkan baik dari lembaga legislatif atau pemerintah daerah harus senantiasa memberikan jaminan perlindungan hukum bagi setiap warganya. Bahkan harus mampu menangkap aspirasi-aspirasi hukum dan keadilan yang berkembang di masyarakat.

Data yang peneliti dapatkan dari hasil penelitian ke Kanwil Kementrian Hukum dan HAM di Kota Serang terdapat beberapa daerah yang telah mendaftarkan Hak Cipta (Seni Batik) diantaranya Kabupaten Pandeglang sebanyak 14 motif, Kabupaten Serang sebanyak 6 motif dan Kabupaten Lebak sebanyak 11 motif. Namun pada data sementara tersebut belum ada motif Batik Banten di Kota Serang yang 
mendaftarkan hak ciptanya Kanwil

Kementrian Hukum dan Ham

Provinsi Banten. Hal ini bisa saja terjadi karena pendaftaran hak cipta dapat dilakukan dari berbagai macam cara. Terdapat banyak media atau alternatif lain untuk mendaftarkan hak cipta selain kepada Kanwil Kementrian Hukum dan Ham daerahnya masing-masing.

Saat ini peneliti belum menemukan adanya kebijakan yang dibuat oleh pemerintah daerah mengenai hak cipta khususnya seni batik di Kota Serang. Padahal hal tersebut dirasa sangat perlu karena seni batik di Banten (Kota Serang) perlu dikembangkan. Dengan adanya peraturan daerah yang mengatur khusus tentang itu akan timbul kesadaran hukum dalam masyarakat. Dengan timbulnya kesadaran hukum tersebut menjadikan industri batik semakin berkembang yang akhirnya akan meningkatkan ekonomi di Kota Serang.

\section{PENUTUP}

\section{Simpulan}

Berdasarkan uraian dalam pembahasan di atas maka disimpulkan beberapa hal berikut maka Perlindungan pada Hak Cipta diatur pada Undang-Undang Nomor 28 Tahun 2014 tentang Hak Cipta meliputi Perlindungan Hak Moral bagi pencipta dan Perlindungan Hak Ekonomibagi pencipta dan pemegang hak cipta. Perlindungan terhadap hak moral berlaku selama pencipta masih hidup dan 70 (tujuh puluh) tahun setelah pencipta meninggal. Belum adanya ketentuan atau pengaturan hukum dalam peraturan daerah di Kota Serang tentang Hak Cipta. Hal tersebut sangat diperlukan khususnya dalam karya seni batik perlu dikembangkan karena Banten sendiri sudah memiliki batik yang khas yang tersebar di daerahnya masing-masing termasuk di Kota Serang. Selanjutnya, perlunya banyak sosialisasi oleh pemerintah daerah setempat akan pentingnya kesadaran hukum untuk mendaftarkan karya seni batiknya agar mendapatkan perlindungan hukum secara pasti. Jika pembentukan peraturan daerah dan sosialisasi terhadap Hak Cipta (batik) dilakukan secara maksimal maka Batik akan menjadi salah sektor dalam peningkatan pendapatan daerah.

\section{Saran}

a. Penulis mengharapkan peran pemerintah daerah dalam penjaminan hukum terhadap hak cipta atas seni batik dengan membuat peraturan perundang-undangan yang khusus untuk hak cipta seni batik agar masyarakat mendapatkan perlindungan hukum secara pasti.

b. Penulis juga mengharapkan kesadaran masyarakat agar mendaftarkan hak ciptanya khususnya seni batik di kota Serang. Karena hal tersebut akan menguntungkan pencipta dan pemegang hak cipta. 


\section{DAFTAR PUSTAKA}

\section{Buku \&Jurnal :}

Abdulkadir Muhammad, Hukum Dan

Penelitian Hukum. PT Citra

Aditya Bajti. Bandung.2004

Devi Rahayu, JurnalMimbar Hukum

:Perlindungan Hukum

Terhadap Hak Cipta Motif

Batik Tanjungbumi Madura,

Vol 23, Nomor 1, Februari

2011.

Margono Suyud, Hukum Hak Cipta Indonesia

(Teori Analisis Harmonisasi

Ketentuan World Trade

Organization (WTO)-TRIPs

Agreement), Bogor: Ghalia Indonesia. 2010

Saidin, Aspek Hukum Hak Kekayaan Intelektual, Jakarta: Raja Grafindo Persada,2003

Tubagus Najib, Batik Banten Mukarnas

Tranformasi Motif

Terwengkal ke Motif Lain, Sengpho Utama, 2012

Palup Trias, Jurnal Negara Hukum:Materi

Baru Dalam Undang-

Undang Nomor 28 Tahun

2014 Tentang Hak Cipta,

Vol.6, No.1, Juli 2015

Sulasno, Adjudikasi :Jurnal Ilmu Hukum:

Penerapan Kekayaan

Intelektual (KI) Terhadap

Umkm Sebagai Upaya

Mewujudkan Persaingan

Bisnis Berkeadilan, Vol.2,

No.2, Desember 2018

\section{Undang-Undang :}

Undang-Undang Nomor 28 Tahun 2014

Tentang Hak Cipta. 